International Journal of Advanced Logistics,

Vol. 1, No. 1, July, 2012, 1-20

\title{
Supply Chain Implications of Sustainable Design Strategies For Electronics Products
}

\author{
R.J. De Coster*, R.J. Bateman and A.V.C. Plant \\ School of Engineering and Design, Brunel University, Uxbridge, Middlesex UB8 3PH, \\ UK
}

\begin{abstract}
Increasing leg islative and con sumer pres sures on manufacturers to improve s ustainability necessitates that manufacturers consider the overall life cycle and not be scope restricted in creating products. Product strategies to improve sus tainability have design implications as many of the decision s made during the design stage will th en determine the environmental performance of the final product. Coordination across the supply chain is potentially beneficial a s products with impro ved energ y ef ficiency ca $\mathrm{n} b$ e b etter re alised. This pap er ex amines tradition al product provision and propos es a s ustainable product de sign process u sing life $\mathrm{c}$ ycle a ssessment (L CA) at $\mathrm{k}$ ey points, as these decision points can provide opportunities for environmental improvements of products. Case studies of consumer and industry products in the electronics sector are examined in terms of improving sustainability by reviewing product a rchitecture and technology solutions. This $p$ aper propo ses methods and an alytical models to better un derstand $s$ ustainable de sign strategies fo $r$ ma nufacturing firm $s$ and $t$ hus aid $m$ anufacturers durin $g$ the earliest s tages of product plan ning to consider alternative product development approa ches whic $\mathrm{h}$ are more sustainable.
\end{abstract}

Keywords: Sustainable Design; Closed Loop Production; Electronics Products; Life Cycle Assessment

\section{Introduction}

The t ypical lif e cy cle stag es for manufactured g oods are shown in Figu re 1 a nd al though environmental improvements can $\mathrm{b}$ e made during these stag es gre ater improvements $\mathrm{c}$ an $\mathrm{be}$ made by viewing the life cycle stages as a "closed loop" rather than an "open loop".

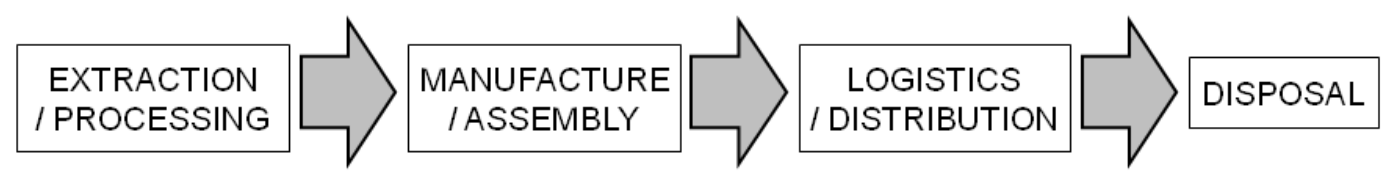

\section{Figure 1: Conventional Life Cycle Stages}

Figure 2 identifies the main life cycle stages for manufactured goods such that sustainability is optimised in a "closed loop" manner. The multi-enterprise organisation can be rega rded as a virtual organisation $(\mathrm{V}-\mathrm{O})$ with the manufacturer as the rec ognized brand leader supported by its associated su pply ch ain. The term $\mathrm{V}$ irtual Org anisation has been used to describe an organisation where almost all tasks have been outsourced, leaving only a small core which has the task of managing the various outsourced parts of the process to ensure they successfully function together (as Hale and Whitham, [1]). 


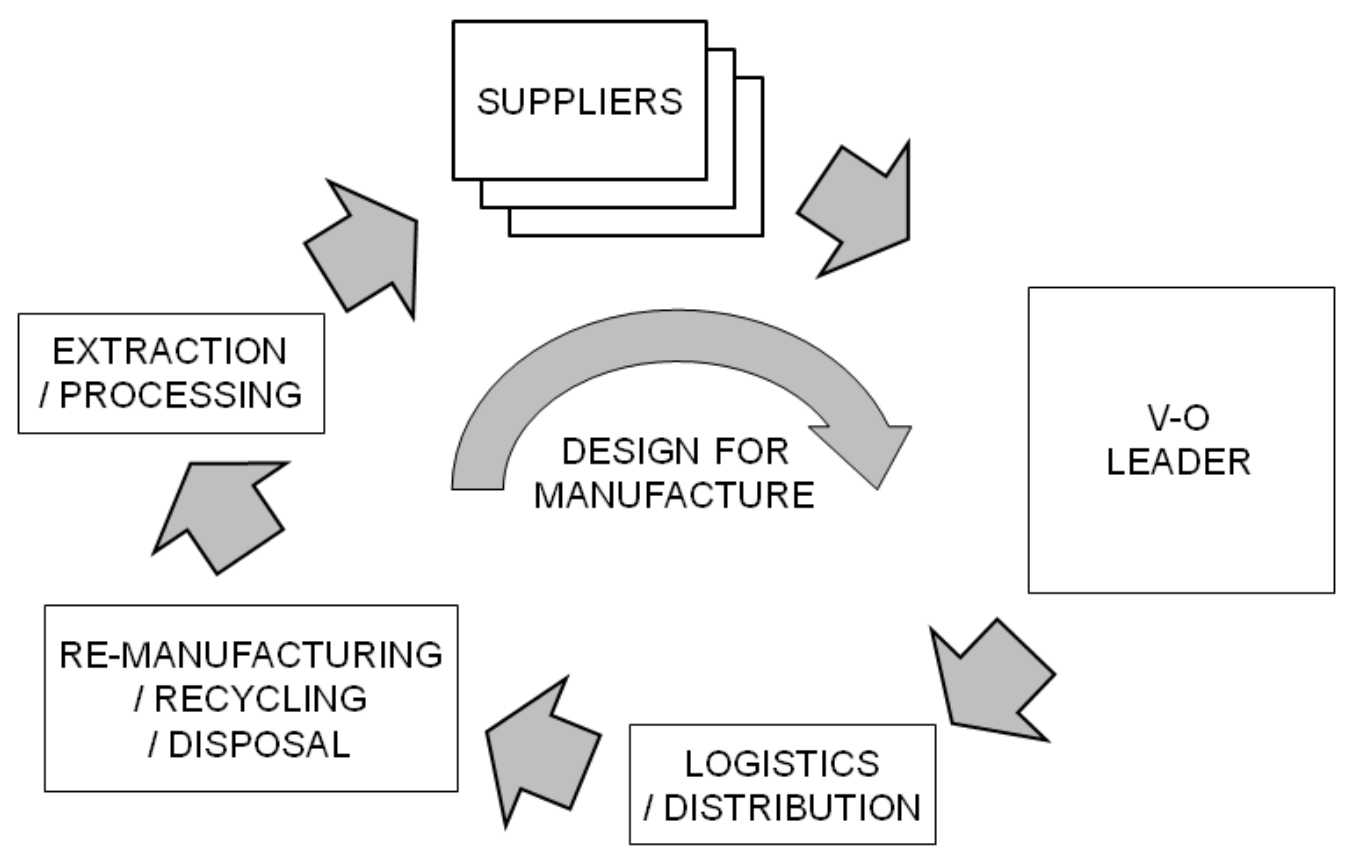

Figure 2: Closed Loop Production

It is not hard to imagine that outsourcing of specific parts of the whole manufacturing process could have $\mathrm{b}$ oth $\mathrm{p}$ ositive an $\mathrm{d}$ neg ative ra mifications o $\mathrm{n}$ an or ganisations drive tow ards sustainability - positive in the sense that it can be built in to the specifications and contract and thus pe rhaps 'e asily' achieved, but negative in the sense that control of suppl iers or subcontractors $\mathrm{m}$ ay prove problematic. $\mathrm{S}$ ustainable $\mathrm{d}$ esign st rategies are considered here for electronic products in terms of o pen lo op versus closed loop prod uction. To im plement the manufacturing and co nsumption of go ods such that sustainability is o ptimised in a " closed loop" $\mathrm{m}$ anner incremental changes a re no $t$ sufficient. We a rgue $t$ hat it is nece ssary for consumption to be improved over the entire life cycle.

Our focus in this paper i s the ea rlier sta ges of the life cy cle for el ectronics products. Both design and production are about adding value through the creation of $u$ seful products. As the process requ ires con siderable in vestment, there sho uld be e conomic advantages to keeping products, or at least parts of them, in use through extended service life strategies. If this is not practically possible then value should be recovered through recycling.

Consumers purchase a wide rang e of elec tronics p roducts $-\mathrm{f}$ rom ho usehold it ems su ch as "white go ods" ( fridge/freezers; di sh washers; wa shing m achines e tc...) through to vacuum cleaners and smaller items for use in the house (su ch a s lighting a nd se curity systems). Computers an $d$ their vario us ac cessories (such as printers an $d$ wire less $n$ etworks) are o ften present in a ho usehold alon $\mathrm{g} \mathrm{w}$ ith televisions an $\mathrm{d} o$ ther en tertainment systems. Further, consumers also pu rchase ele ctronics prod ucts for personal usage su ch as portable music devices and mobile phones. The range of electronics products is growing and consumers may have se veral portable devices - su ch as Sat Nav (satellite $\mathrm{n}$ avigation systems). Advan ces in technology brings new devices to con sumers such as electronic notebooks (such as the iPad 
from Ap ple) wh ich all ow ea sy a nd con venient viewing of $d$ igital con tent su ch a s enewspapers; e-mails through to e-books

The proliferation of electronic devices has been advantageous to both the firms supplying the products (th e vendors and th eir distributors) with the $r$ esulting incre ase in revenues (an $d$ associated profit) as well as to the end consumers who have a myriad of devices with which to interact and make use of in their increasingly 'content rich' lifestyles. However, from a societal perspective it is very wasteful for more and more electronics devices to be manufactured and operated a s 'consumption' of resou rces is increased at bo th an ind ividual and sy stem level. Design strategies to provide up grades in ter ms of functionality without the need to $p$ urchase new electronics devices need to be embraced to improve sustainability [2].

Retailers in the UK ha ve be en interacting with con sumers wh ose living cos ts are ri sing including their en ergy costs and th is has raised interest with many consumers in terms of the energy usage and en ergy saving featur es a vailable on the p roducts they inte nd to pu rchase. White goods are frequently kept by households for many years and therefore the payback of energy efficient equipment is like ly to be realised by households. Consumers are increasingly including energy c onsiderations as pa rt of their a ssessment whe $\mathrm{n}$ purchasing electronics products such as ho usehold items. To include energy considerations in the ir decision making consumers need to have access to product in formation relating to the product's en ergy usage and any energy saving fe atures. Th is r requires that the la belling of products needs to include energy consumption and needs to become part of the merchandising process.

Labelling becomes a important as it p rovides a means for con sumers to assess th e energy performance of the white goods. Terms relating to energy consumption may not be understood by con sumers although the cost $\mathrm{i}$ mplications will be. This ne cessitates that information concerning the energy usage of prod ucts needs to be made both a vailable and accessible (so that it is und erstood by consumers). Con sumers are increasingly aware $t$ hat their usage of products and their daily habits have an associated energy and hence cost implication and are making use of features such as dimmer switches for lowering lighting levels and other energy saving features. However preparation of such energy usage information comes at a cost and this may not always prove tenable as illu strated in the UK by the recent decision to withdraw the Home Information Pack or 'HIP'.

The provision and manufacture of products in ways that are truly sustainable are inhibited by three issu es: firstly, deci sions a re predominantly made so lely from th e persp ective of the "vendor" (and do not con sider the wid er perspective); seco ndly, th at gen erally the scop e of business planning is still rooted in production/manufacturing costs (and not consumption costs) and thirdly, the cu rrent performance measures (e.g. KPIs) mainly focus on profitability. The rationale for this paper is the argument that there is a need to raise the awareness during the earliest $\mathrm{s}$ tages of p roduct planning that there may be alternative a pproaches wh ich are more sustainable. The con cepts $p$ resented h ere will underpin $f$ urther research into perfor mance measures which encompass sustainability and resulting business planning implications.

\section{Design approaches}

Product strategies to improve sustainability have design implications as many of the decisions made during the design stage will then determine the environmental performance of the final product. Coordination across the supply chain is potentially beneficial as energy constraints of the end user need to be recognised and responded to which may involve substituting parts and 
components to realise products with improved energy performance such as dimmer switches for low ering lighting levels. Design strategies of the major brands of electronics products are often focused 'in-house' an d preclude consultations with the ir suppliers earlier in the supply chain. This m ay limit the potential for improving the en vironmental performance of the final product. For example, washing $m$ achines hav e been intro duced with wash ing cycles that operate at a lo wer temperature with the asso ciated energy savings of not having to heat water to such a high temperature. These products are best realised when developed in conjunction with the firms that $p$ rovide the washing $p$ owders as these $n$ eed to perform at the lower temperatures or consumers will be deterred from using low temperature cycles.

To improve sustainability we need to move towards "a corporate system that integrates product and d esign issues with issu es of $\mathrm{p}$ roduction planning and control and su pply ch ain management in such a manner a s to iden tify, quantify, asse ss and manage the flow of environmental waste with the g oal of redu cing and ultimately minimizing its im pact on the environment, while a lso trying to maximize r esource e fficiency" as c ited by Ellram et al p. $1620[3]$.

Environmental life cy cle asse ssment (LCA) as a m ethod to enable en vironmental product informational needs has been recognised fairly recently by Miettinen and Hämäläinen [4]. It enables qu antification of product spec ifications so th at a lternate designs $\mathrm{c}$ an $\mathrm{b}$ e a ssessed in terms of the ecological impact by $\mathrm{c}$ haracterising p roduct a ttributes a nd $\mathrm{k}$ ey e lements. This approach ca $\mathrm{n}$ be compared to $\mathrm{t}$ he use of simulation tools wh ich are used to characterise manufacturing processes and then examine various process configurations. The end results of the simulation calculations are oft en display ed visually as this emphasises the differences of the con figurations test ed. The $\mathrm{d}$ evelopment of a sim ulation model is tailore $\mathrm{d}$ to a given situation and this will also be the $\mathrm{c}$ ase for environmental LCA where each product type will need a tailored assessment.

The org anisational im plications of design approaches that u tilise LCA can be co nsidered similar to that of concurrent engineering (CE): "while traditional NPD focuses specifically on the product, concurrent engineering (CE) rep resents a revolution of new product development thought by sim ultaneously focusing o n pro duct and process using cross-functional te ams" quotes Ellram et al p. 1621 [3]. However, due to its popularity, CE by itself no longer provides a source of competitive advantage. Further, "in companies that now practice two-dimensional concurrent e ngineering ( $p$ roduct and process only), sup ply chain dev elopment tend s to be haphazard" states Ellram et al p. 1621 [3].

The UK has been transitioning its broadcast television systems from analogue to d igital. For several years there has been a period of overlap during which households have been able to use their existing analog ue $t$ elevisions to $v$ iew programmes. Ho wever, the cutoff $f$ or a nalogue transmission is in prog ress arou nd the UK which $\mathrm{h}$ as meant that households with a nalogue televisions are $\mathrm{n}$ o lon ger able to view pro grammes un less they buy a digital convertor box (which a re r elatively cheap) o $r$ so me alternative (such as Free Sat). Many households a re deterred by the $\mathrm{h}$ igh monthly subscription costs of se rvices from satellite sup pliers offering premium channels particularly those with families and the associated living expenses.

Retailers of televisions in the UK have seen consumers upgrading or replacing their televisions due to the sw itch over to d igital broadcasting. The environmental impact has been evident as many h ouseholds have taken the op portunity to upg rade the ir televisions from the old CR T 
(cathode ray tube) te chnology to the $\mathrm{n}$ ew flat $\mathrm{s}$ creen televisions which u sually come with a digital rece iver bu ilt in. Re tailers hav e b een a dvising consumers on their o ptions an d have supported many consumers by taking in their old televisions when they bring them to the store following the purchase and successful installation of the $\mathrm{n}$ ew flat screen televisions. This has demonstrated on a nati onal scale the ty pe o f o rganisation requ ired to $h$ andle con sumer electronics products at the EOL (end-of-life) stage.

Considerations of $d$ esign app roaches which add ress the EOL incl ude DfE (Design -forenvironment): "in general, DfE is a d esign process in which a prod uct's environmentally preferable a ttributes - including rec yclability, disassembly, maintainability, refurbishability, and reusab ility - are tre ated a s design objectives rath er than as constraints. D fE g ives guidelines for the design eng ineer to examine en vironmental soundness of a $p$ roduct ov er its entire life cycle by introducing modifications early in the product design process" states Pujari et al. 2004 in Bereketli et al. p. 214 [3]. Further, "the argument can effectively be made that all waste begins $w$ ith the design practices of an organization. In design ing products, processe s and sup ply c hains that do not sp ecifically con sider en vironmental impact, organizations implicitly design for waste rather than for environment" as cited by Ellram et al p. 1626 [3].

Within the home there are many different applications for which consumers obtain electronics products. Each application is con sidered by consumers prior to purchase of p roducts in terms of 'cost versus benefits'. However the 'cost' as pect is argu ably to o limite d in perspective as decisions con cerning the vario us devices tend to be made independently. This can lead to a proliferation of device $\mathrm{s}$ be ing present in the home including sev eral previous generations of devices many of which $\mathrm{h}$ ave assoc iated items su ch as aux iliary $\mathrm{p}$ arts (such a s b attery rechargers etc..). It is fairly co mmon th at several $g$ enerations of mobile pho nes; co mputers; cameras and other entertainment products have been purchased. Arguably we need to re-think the very nature of products and their pu rchase ac cording to Birkeland p. 12 [5]: "Given the urgency of ed ucation for susta inability, $t$ he $p$ riority needs $t o$ shift to the training an $d$ professional developments of pre sent a nd future de cision makers. Bo ardrooms a nd b ranch managers generally do not design systems but they determine who does. Managers (whether trained in science, technology, business, economics, planning or engineering) make decisions and instruct sta ff in matters of technology and p roduction ch oices that can $h$ ave 1 ong ter $\mathrm{m}$ environmental consequences. Further managers are in a better position to set systems in place that r educe e nvironmental im pacts through management tools such as pu rchasing practices, product stewardship and leasing agreements, environmental management plans, energy audits, and so on".

The scope of e nvironmental standards is far broader an d more complex than that of quality standards. En vironmental management sy stems span all of the interactions b etween a company, its ph ysical env ironment, and i ts st akeholders inc luding custo mers, stock holders, regulators, suppliers, communities, interest groups and employees according to Fiksel p. 28 [6]. One defin ition of gre en supply chai $n$ management (GSCM) is f rom Srivastava (cited in Bereketli et al. p. 213 [2]). His study collected and classified previous lit eratures re lating to green supply chain management. He defined GSCM as "integrating environment thinking into supply chain management, including $\mathrm{p}$ roduct $\mathrm{d}$ esign, material so urcing an $\mathrm{d}$ selection, manufacturing processes, deliv ery of $t$ he fina 1 pr oduct to the co nsumers, and end -of-life management of the product after its useful life." 


\section{Sustainable product development}

Innovation strategy is a part of a firm's overall strategy and develops strategies for managing technology and innovation as identified by Cooper [7] in his work on product innovation and technology strategy (PITS): the need to identify and specify the types of markets / applications / technologies and products which a firm's new products will follow. This strategic level may utilise a number of planning tools such as the product-technology roadmap which encompasses the $\mathrm{m}$ ore recent strategic management litera ture concern ing a firm's competences as recognized by Prahalad and Hamel [8].

Recent interest in including ecolog ical aspects into pro duct dev elopment ha s high lighted a number of tools such as an "Eco-Ro admap" wh ich according to Tischner and Nickel [9] is comparable to the p roduct-technology roadmap but with a focus on sustainability. Th is "topdown" strategic approach has its merits however the reality of product development in many firms is that other tools or methods a re required which do no $t$ rely on s ustainability a $t$ a strategic leve 1. The ability to renew competences in order to ac hieve congruence wit h the changing business environment is referred to as dynamic capabilities according to Fahy [10]. These dynamic capabilities are e mphasized by Eisen hardt and Martin [11] as en tities wh ich enable a firm to ach ieve $\mathrm{n}$ ew an $\mathrm{d}$ inn ovative forms of competitive ad vantage. Dy namic capabilities a re argu ed to be a $\mathrm{k}$ ey part of the ratio nale u nderpinning stra tegic management according to Tee ce et a 1 [12 ]. The y ar gue that a firm's focu s sho uld be o n de veloping the firm's capabilities - not its products.

The model proposed here is on e that utilises life cycle assessment (LCA) at a number of key "decision points" for produ ct plann ing as sho wn in Fi gure 3. These are shown as three "circles" which use LCA to asse ss the po tential env ironmental im pact at different levels of detail to support product planning decisions. The three LCA concern: firstly, life cycle costing, secondly, life cycle design and thirdly, life cycle analysis.

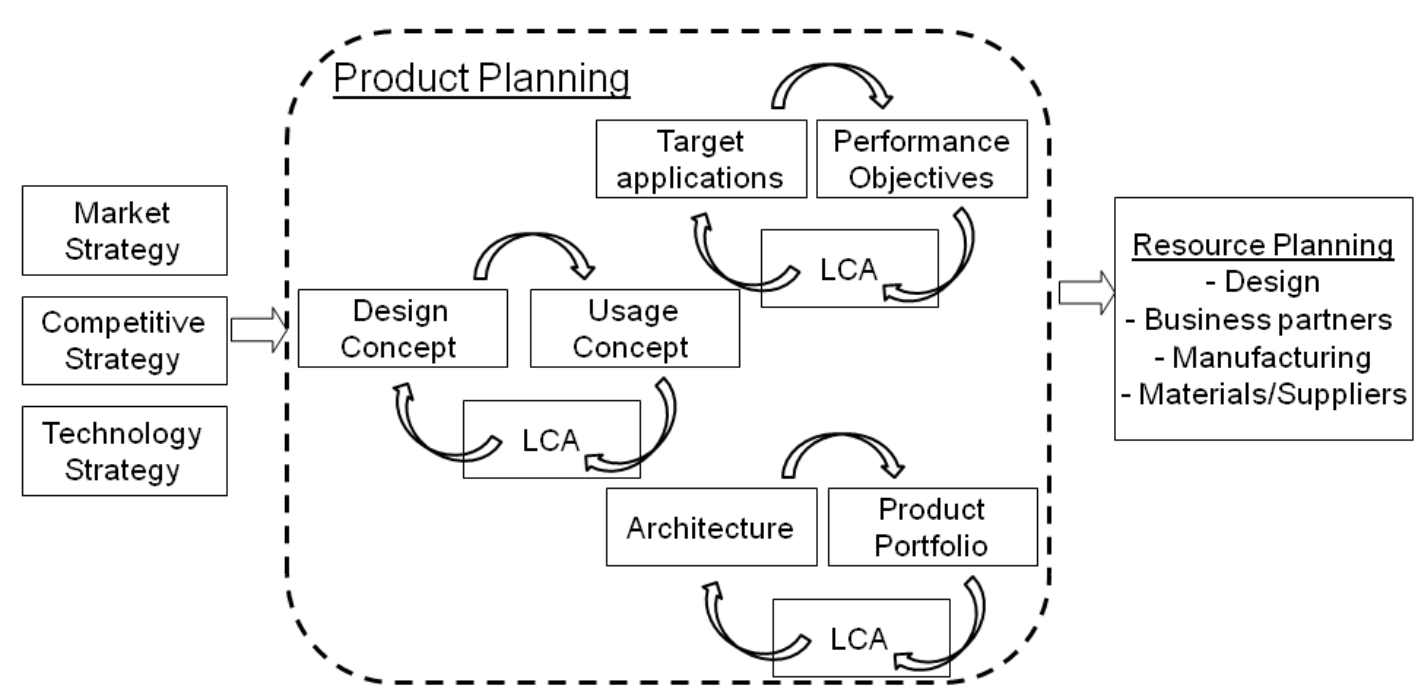

Figure 3. Sustainable product development process 
The three life cycle assessment at key decision points during the product planning phase will assess environmental $\mathrm{p}$ erformance an $\mathrm{d}$ thu $\mathrm{s}$ provide o pportunities $\mathrm{f}$ or e nvironmental improvements according to Maxwell et al [13]. High technology firms already have to weigh up a $\mathrm{n}$ umber of resource and techn ological constraints du ring the product planning phase as well as external considerations such customer value provision and competitive pricing. The use of life cycle assessment will provide a structured way of enhancing the decision making i.e. it will bring sustainability to the forefront of a product development process without disrupting the established practices of a firm.

The prop osed p roduct development process is o ne that includes LCA at the concept development stage o f the design process which e nables a ssessment of e nvironmental performance. The model proposed here is one that utilises life cycle assessment at a number of key "decision po ints" for p roduct p lanning as sh own in F igure 4 . These are sho wn as th ree "circles" which use LCA to asse ss the po tential env ironmental impact at different levels of detail to sup port product planning decisions. The three LCA stages are also shown in Table 1 which includes examples.

The first LCA concerns life cycle costing and assesses the attributes of a product which may be represented as a decision tree where alternatives are identified. This according to Miettinen and Hämäläinen [14] is a less detailed life cycle assessment with the use of categories (of high vs medium v s low) to make a "rela tive" assessm ent rat her than an "absolute" (q uantitatively based) assessment. This $p$ rovides a mo re general $v$ aluation of alternative design concepts which is comm only used in the early st ages of new p roduct $d$ evelopment by the use of weighting systems. The intent here is to encourage the consideration of alternatives which may be more sustainable at this early design stage such as the use of technologies that require less landfill. This less detailed analy sis has the advantage in that it encourages an assessment that has a wider scope.

The second LCA concerns life cycle design and concerns the more strategic aspects relating to technology management - architecture decisions and product portfolio planning. Architecture decisions ca $\mathrm{n}$ provide a co mpetitive a dvantage to fir $\mathrm{ms}$ wh ilst prod uct portfolio decisions should sup port a firm's market plans. These decisions can e ither sup port or rest rict a firm's position as so me architecture types lend themselves to supporting sustainable initiatives more than o thers. Clearly defined modules or co mponents and their in terfaces sup port equip ment upgrades e pitomised by the $\mathrm{c}$ omputing secto $\mathrm{r}$ and the design of $\mathrm{p}$ ersonal computers which anticipated the need to upgrade disk drives and other key components.

The third LCA concerns life cycle analysis and takes the proposed product and makes a more detailed assess ment of the e nvironmental im pact $f$ rom produ ction on wards which may comprise three main life cycle aspects identified by Schmidt and Butt [15]: production of the product; the user phase and the end of life environmental costs. The environmental cost of the production of the product is not disc ussed here as it is well understood. The assessment of the user phase will $\mathrm{v}$ ary depending o $\mathrm{n}$ the prod uct concerned, for example, it $\mathrm{w}$ ill examine the environmental impact of the use of the product such as e missions from vehicles. It $\mathrm{w}$ ill also need to assess user maintenance and other running costs which will require modelling ty pical scenarios based on anticipated usage patterns (for example, annual mileage and typical vehicle speeds). 
Table 1. Life cycle assessment for sustainable product development

\begin{tabular}{|l|l|l|}
\hline $\begin{array}{l}\text { Life Cycl } \\
\text { Assessment (LCA) }\end{array}$ & Focus & Examples \\
\hline 1) Life cycle costing & $\begin{array}{l}\text { Supply chain elements: } \\
\text { i) Suppliers } \\
\text { ii) Vendors } \\
\text { iii) Customers }\end{array}$ & $\begin{array}{l}\text { Military Aircra ft: Product- } \\
\text { Service Systems (PSS) }\end{array}$ \\
\hline 2) Life cycle design & $\begin{array}{l}\text { Extending usage through Technology } \\
\text { Management: }\end{array}$ & $\begin{array}{l}\text { Computers: } \\
\text { Modular de sign for u ser } \\
\text { upgrades (g raphics cards } \\
\text { etc..) }\end{array}$ \\
& i) Architecture & $\begin{array}{l}\text { Automotive sec tor: v ehicle } \\
\text { manufacture a nd EoL } \\
\text { ii) Product portfolio planning }\end{array}$ \\
\hline 3) Life cycle analysis & Environmental impact (Schmidt and \\
& Butt, 2006): & \\
& i) Product creation & \\
& ii) User Phase & \\
& iii) EoL costs & \\
\hline
\end{tabular}

These detailed assess ments will need to iden tify the life cycle stag es and the resources use (materials; energy and other resources) to con duct a detailed assessment of the en vironmental impact. For example, a stu dy rep orted by Joshi [16] comparing the life cy cle environmental performance of steel and plastic automobile fuel $t$ ank systems assessed nearly thirty items along each of the life cycle stages. Studies report that the end of life environmental co sts are usually b elow 5\% according to Sch midt and Butt [15], however, for industries wit h large production volumes these are still significant.

\section{Sustainable product planning}

In the seventies successful tech nology firms comprised large vertically-integrated firms. The advantages according to Jiao and Tseng [17] were that technically advanced products could be developed by c arefully coordinating i nterface specifications and other de sign para meters between departments. The advancement of technology is a major external factor for firms with the organisational model of traditional businesses becoming irrelevant. In the Internet era the loose organisational structures requ ire mechanisms to en sure successful innovation in cluding the transfer from design to $\mathrm{p}$ roduction. A gen eric traditional prod uct development process is shown in Figure 4.

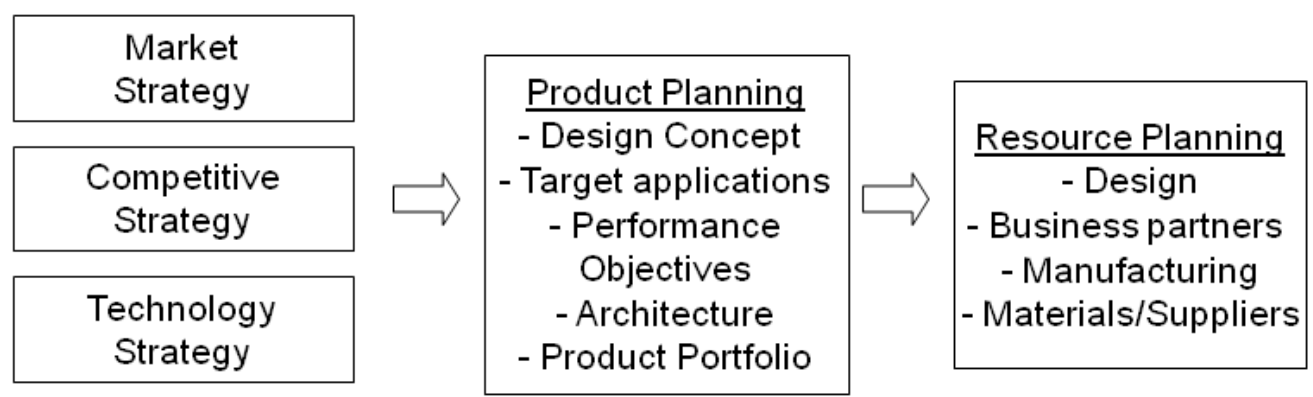

Figure 4: Generic traditional product development process 


\subsection{Product planning drivers}

External factors of the marketplace along wit $\mathrm{h}$ th ree general factors comprising price sensitivity; performance expectations and regulatory constraints and organisational factors are the general factors that influence product design according to Noble and Kumar [18]. Product design has been well reported in the main stream literature by leading writers such as Cooper [7] with re cent e mphasis o $\mathrm{n}$ fast er time-to-market (TTM), o pen lea rning and im proved ergonomics each of which is now discussed.

4.1.1 Faster time-to-market: Manufacturing firms are increasingly pressurised to deliver new products to the market in shorter timescales which is challenging as technology advances and becomes inherently more co mplicated to engineer and $m$ anage $\mathrm{n}$ ew $\mathrm{p}$ roduct development. Firms have invested in solutions such CAD systems which provide 3D visualization solutions that en able the new product $d$ evelopment process $t$ o be reduced. The benefits of fa st development processes are that firms are in a position exploit new or e merging applications. These new or e merging applications may arise from the interaction among components once new technologies are in plac e i.e. it $\mathrm{s}$ hard to anticipate and plan for these e merging opportunities.

4.1.2 Open learning: The resources required to develop new technologies are prohibitive even for the larger companies and cause many firms to look outside the firm to access technology. A firm may o rganise their produ ct modules or st ructures into "bu ilding block s" to effic iently support pla tform d evelopment projects. However, the y may still $\mathrm{n}$ eed to make use o f other firm's knowledge and e ven a cquire specialist technology co mpanies wit h a t echnological competence in an emerging area which may enhance or improve the functional performance of their pro duct or s ystem. Competitive adv antage ba sed on core co mpetencies has beco me a recognised $\mathrm{p}$ art of strategic thinking wh ere the d evelopment of the $\mathrm{n}$ ecessary competences (technological or otherwise) of a firm involves accessing external knowledge as well as relying on internal knowledge building activities according to Chesborough and Teece [19].

The benefits of innovation strategies involving collaboration is one which is driven by resource limitations. As $t$ echnology advances it $b$ ecomes i ncreasingly $d$ ifficult $f$ or fi rms to hav e resources o f su fficient b readth and $d$ epth $i \mathrm{n}$ the re quired technological areas. This is problematic as the extent literature on strategic management and how firms compete puts great emphasis on a firm's capabilities. This perspective is the $r$ esource based view ( RBV) of the firm and is based around the recognition and development of core competences as epitomised by Prah alad an d Ha mel [8]. How ever, it is re cognised by Galliv an [20] th at trust and other issues become a factor during inter-firm projects and operations.

4.1.3 Improved Ergonomics: The brand of many major vendors of consumer products (e.g. Nokia), need protecting which requires product concepts whose design and user friendliness is going to attract consumers across global markets. Manufacturers with expertise in Global DFM (design-for-manufacture) will requ ire a co mpetence in product des ign which is highly ergonomic as con sumers increasingly a re time pressured and mobile thus wanting prod ucts which are $\mathrm{h}$ ighly intuitive. Go ne are th e days when consumers will accept purchasing video recorders wh ich were so inv olved to program that the majority of con sumers either were unable to record a television program or were unwilling to expend the required effort. Not only is ease-of-use a key issue for consumers but also the visual product aesthetics which must fit today's lifestyle conscious consumers as discussed by Noble and Kumar [18]. 


\subsection{Project selection}

Many p otential ideas or $p$ rojects may be identified and these need to $b$ e ev aluated and the appropriate proje cts sele cted for dev elopment. This $n$ arrowing of projects i $\mathrm{s}$ known as $\mathrm{t}$ he 'development fun nel' a s shown in Figure 5. Project selection i s based on a nu mber of considerations ranging from financial measures (profitability; return and payback) through to strategic con siderations (fit w ith the firm's bu siness go als) through to resource av ailability. Further, prioritization of projects may be based on existing products and customers including commitments made and the fit with the ex isting produ ct $\mathrm{p}$ ortfolio. Sustainability aspects a re not traditionally considered during the project selection process.

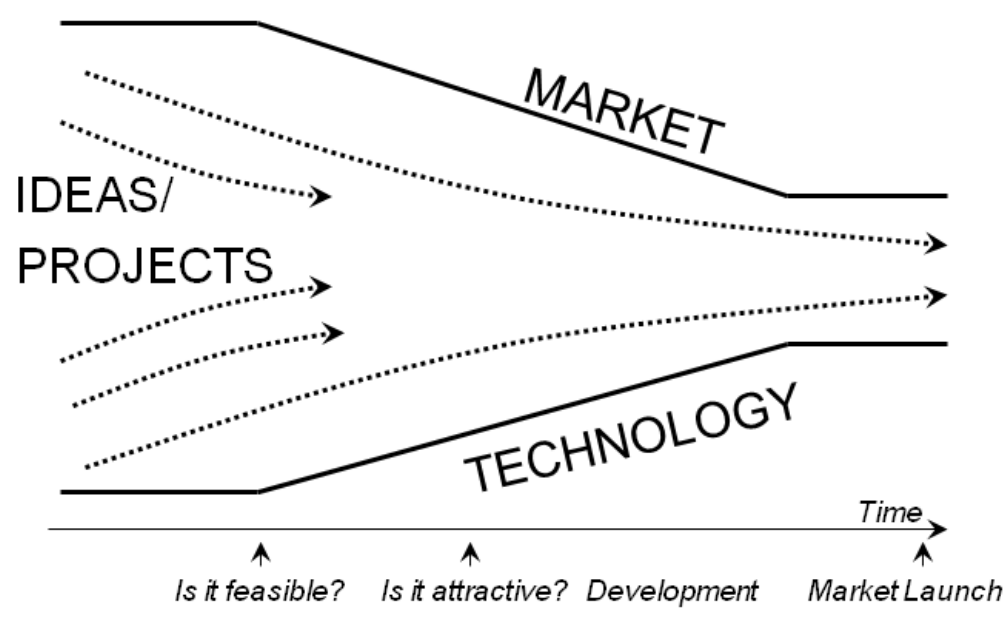

Figure 5. The innovation and new product development funnel 
The $\mathrm{p}$ roduct $\mathrm{d}$ evelopment process proposed in th is $\mathrm{p}$ aper is one that inc ludes life $\mathrm{c}$ ycle assessment (LCA) at the concept development stage of the design process which according to Maxwell e $t$ al [1 3] enables assessm ent of environmental performance. Th is is a broader assessment of a new product than the traditional approach of strategic; market and finan cial cost bene fit analysis. Given the co mpetitive $\mathrm{p}$ ressures on firms and the need to bring new products to market in a tim ely manner; the need to consider environmental impacts during the product development process may not be realized by firms. However, the increasing legislative requirements (concerning em issions etc..) alo ng with the $g$ rowing a wareness a mongst consumers and other parties has necessitated that firm's consider the environmental impacts of their products and business operations.

LCA is one of the "tools" for improving sustainability, how ever, a broader "systems view" is necessary to align manufacturing activities with the usage of goods to be more congruent. The argument here $\mathrm{i} \mathrm{s}$ that su stainable production (from ma nufacturing through to consumption through to d isposal) needs revie ws of o rganisational struc tures includ ing the ov erall sup ply chain. We argue that the following aspects must be considered to implement design for closed loop:

- The production perspective: the manufacturing of the goods is the "engine" of the enterprise operations which drives a business enterprise

- The people perspective : a shift in thinking and also behaviours - $b$ oth for sta ff $w$ ithin the vendor as well as end users and other organizations

- The financial p erspective: the co st implications a nd business case asp ects - bo th for the vendor as well as other organizations

To improve the environmental impact of innovation and new product development measures are $\mathrm{n}$ eeded to encourage co nsideration of alternative technologies and so lutions (such as alternative technologies for automotives) as well as a more "end-to-end" perspective of "cradle to grave'. We now examine some case studies which provide examples of innovation and new product developments.

\section{Sustainable design strategies practice}

One of the major problems for any manufacturing organisation is movement towards a goal of sustainability wh en that go al is difficult to define. W hat and whe re i s the s ustainability? Increasingly manufacturers talk of $\mathrm{p}$ roducing 'su stainable' products as the ir rou te to sustainable manufacturing however both $p$ roducts and their manufacturing processes need to be sustainable for any approach to be called truly sustainable. For ex ample the use of timber sourced from sustain able sources (e.g. b earing the F orest S tewardship Co uncil (FSC) mark) may be used to promote the 'green credentials' of a company but the equipment, methods and processes used to manufacture the products may have remained unchanged for decades.

Sustainability is $b$ roader in scope than making a more environmentally friendly product as it needs to encompass the whole life cycle. A drive towards lower energy and resource usage (e.g. through lean manufacturing) is n ot nec essarily the sa me as a sustainab le app roach - sim ple reduction of en ergy and/or resources used in manufacture with no attempt to 'close the loop' will effectively only result in resources and energy taking longer to 'run out'. Ex actly what sustainability is, is not clear and the problem of defining sustainability remains as highlighted by Scho ltz and Tietje [21 ]. In fact Jacques et a 1 [22] con cluded that "... p ointing o ut the 
reasons why products are not sustainable is typically easier than defining all the attributes that would make a product so...".

The approach that we shall take here towards this is to examine and compare DFM (design for manufacturing) against $\mathrm{c}$ losed loop design. The advantage of this ap proach is that DFM is a well established approach that recognizes that the majority of the co st for a manufacturer in a project or product life cycle occurs during the production phase. The scope of the design phase is enhanced such that the focus is not restricted to the product that will be produced but also the practical aspects of the manufacturing of the product.

The shift in mindset for DF $\mathrm{M}$ is towards one whe re firms op timize the product and the manufacturing process. This $\mathrm{n}$ ecessitates that the designers consider a later stage of the $\mathrm{v}$ alue chain - a shift in thinking that is also required for closed loop design. The difference being that DFM r equires an understanding of manufacturing a ctivities which are often within the same organisation (if no $t$ the same site), however, closed loop design requires an understanding of the usage and later life cycle stages which occur outside of the manufacturing organisation.

\subsection{Case study analysis}

Design for closed loop is not widespread amongst manufacturing firms; however, our research has highlighted examples of practices which we now consider.

5.1.1 Case Study 1 - aircraft components: The development of the 777 generation of aircraft by Boeing as the world's first aircraft developed completely 'virtually' is w ell publicised and documented. Virtual manufacturing utilises e-manufacturing systems and computer simulation to model real world manufacturing processes to enable optimisation prior to manufacturing.

Using computer ai ded design (CAD) systems as a principle driver, more than 1,700 Bo eing engineers and designers develop ed the three million plus parts $\mathrm{f}$ or the 777 , assembled them virtually, tested the assembled plane with various virtual human passengers made appropriate modifications and improvements without a ny $p$ hysical $p$ arts being neede $d$. Once t he manufacturing process was begun, the improved level of information and instruction available gave great benefit to the end product, saving Boeing large a mounts of time and money in the development of an extremely complex machine.

5.1.2 Ca se Study 2 - semico nductor $m$ anufacturing: The Ta iwan $\mathrm{Se}$ miconductor Manufacturing Company (TSMC) is one of the largest dedicated integrated circuit producers. In the late 1990's, TSMC reengineered their business along the lines of a virtual factory (VF) to differentiate themselves from their competitors and streng then ties between them and their customers.

By use o f system integration soft ware, the company brought to gether engineering systems, product da ta management ( PDM) systems, manufacturing sy stems an d ente rprise re source planning (ERP) systems to enable customers to place orders and receive confirmation feedback in real-time, share eng ineering data and track work-in-progress (WIP) in real time. The new system has helped customers save large a mounts of money and improve development times. These closed loop design app roaches enable inv entory reductions wh ilst a lso resulting in improvements in cycle time with the added bonus of improved customer satisfaction. 
5.1.3 Case study 3 - mobile phones: Manufacturing firms are facing the dilemma of utilising increasingly complex technology to meet the ir bu siness needs wh ilst trying to operate cost effectively in a globally competitive environment. Opportunities for manufacturing sustainable products need to be rea listic and ad apt a manufacturing firm's operations rather than disrupt ongoing business operations. It is easiest to examine an example application to appreciate the various elements involved. Here we consider the example of mobile handsets which are used by people to p rovide communications; entertainment; corporate and other applications. There are an increa sing n umber of mobile user dev ices which need to be sup ported - bo th for industrial purposes and for consumer electronics. There has been a gradually evolving range of mobile dev ices which is extend ing as differe $n t g$ roups of $u$ sers see the benefits of wire less connectivity, for example, healthcare for home patient monitoring.

The design aspects for each device, service and application need to address the service concept aspects and the mobile us er interface design to ensu re usability. The g rowth in d iversity of mobile devices is yet to occur and includes Smartphones, PDAs, Portable Media Centers, retail point-of-sale systems, G lobal Po sitioning System-based dev ices and i ndustrial rob ots. This increasing num ber of user devices are challenging to support as they each have diffe rent interface requirements. By u sing software so lutions rather th an hardware to handle the protocol processing the environmental impact of products are red uced and the ir useful life is extended as software is easily upgradeable.

5.1.4 Case study 4 - cooling units: Refrigeration sy stems are widely deployed in the food sector for the purposes of transp orting a nd storing goods (su ch as milk) at the appropriate temperatures. Cooling un its are th us requ ired du ring the $\mathrm{p}$ roduction $\mathrm{p}$ rocess; transportation (often in specialised vehicles) and at distribution/retail sites such as food stores; supermarkets and restaurants.

In response to the Mon treal Protocol and associated European legislation designed to prevent the depletion of the ozon e layer, manufacturers have had to change chlorofluorocarbon (CFC) refrigerants for gases with lower environmental impact such as hydrofluorocarbons (HFCs) or hydrocarbons. The development of machines that use $\mathrm{CO} 2$ as the refrigerant is an example of an initiative to further minimise impact as $\mathrm{CO} 2$ has a relatively low global warming potential. However, $\mathrm{CO} 2$ can b e problematic to use as a working fluid because of the higher pressures required and greater o perational energ y c onsumption. W ith older models of fridges, CF Cs were often $u$ sed as the blow ing a gent for the insu lation foam. Today the fo ams for this application are more environmentally benign.

\subsection{Closed loop manufacturing}

A number of concepts and ideas for sustainability have been developed like g reen design for manufacturing, de sign for the environment (DF E) or e nvironmentally c onscious d esign and manufacturing, which attempt to consider all environmental aspects of the materials, products operations and processes $\mathrm{w}$ ith the intention that they $\mathrm{c}$ an be co nsidered at the very earl iest stages of design and manufacture. Cradle to cradle (C2C) is a term coined in the 1970s and has been developed by a number of researchers since according to McDon ough, et a 1 [23 ]. It considers the impact of each stage from mining of raw materials through to recycling, paying particular emphasis on:

- sustainable and efficient manufacturing using clean technologies;

- waste free production; 
- use of non-hazardous and recyclable materials;

- reducing energy consumption;

- renewable energy sources;

- minimisation of environmental impact; local sourcing of materials and energy;

- continuous review of the possibilities of reuse and recycling of materials.

In 'Cradle to Crad le' [Mc Donough an d Braungart, 20 02] u sed materials, from wh at wo uld otherwise b e waste prod ucts, are reg arded as e ither 'te chnical nu trients' or 'biolog ical nutrients'. Appropriately design ed EOL p roducts $b$ ecome inputs to the recy cling process. Certain types of $\mathrm{m}$ anufacturing wast e could also $\mathrm{b}$ e reg arded a s techn ical $\mathrm{n}$ utrients. So me producers go be yond des ign for materials recy cling, a nd d esign and plan $\mathrm{f}$ or prod uct refurbishment or re manufacture. Using this ty pe of $\mathrm{c}$ losed loop s ystem, increases the opportunity to retain some of the original investment and energy embodied in products during their initial manufacture. These options can often be less en vironmentally damaging and more economically valuable than limiting reprocessing to the recycling of materials.

Design for Recycling (DFR) uses pro cesses from the natural world to conceptualise recycling activities. For example, the 'biological' cycle - where org anic materials naturally degrade into new 'soil' to allow the growth and development of new life (product which function for their life and then can be safely discarded) and the 'industrial' cycle in which the materials in the product are recycled and reused con tinuously (as in the recycling of alu minium drinks cans reducing production costs by $60-70 \%$ and pollution by up to $90 \%$ ).

Manufacturing firms are facing the dilemma of utilizing increasingly complex technology to meet their bu siness needs $w$ hilst trying to o perate c ost e ffectively in a glob ally co mpetitive environment. Op portunities for manufacturing sustain able p roducts need to be rea listic and adapt a manufacturing firm's op erations rather than disrupt ongoing business o perations. To close the loop in manufacturing te rms, the id eal so lution w ould be to $\mathrm{b}$ e ab le to use scrap, waste material, broken parts, etc. a s direct input raw material for the manufacturing process. In on e sense this principle can not exa ctly be sai $d$ to be new - for exa mple in the jewe llery industry, great care is taken to save even the smallest amount of gold, silver or other precious metal filings, sw arf, e tc. cre ated wh en the sur faces and features of cast ite ms like ring s or broaches are smoothed or fin ished. The scrap material is then (litera lly) added to the "melting pot' re ady for the new ca sting c ycle. The main drivers here are the high cost of the raw material and the ease with which it can be directly incorporated into the manufacturing process with no requirement to reprocess, refine or sep arate needed. Ste el, aluminium, etc. scrap and swarf from conventional machining processes is of course routinely collected for recycling but this in evitably occurs at so me location far re moved from the manufacturing facility like a foundry. Unfortunately, opportunities $\mathrm{f}$ or $\mathrm{c}$ ontamination $\mathrm{c}$ an then occur throughout $\mathrm{t}$ he collection process

The ease of direct reuse and a lso ease of rec ycling of scr ap and w aste material is stron gly dependant on the simplicity of the $b$ asic material. Single materials with $p$ roperties wh ich remain unchanged before and after the manufacturing process, like many metals and plastics are thus the most likely to be able to be easily reused either directly or indirectly. "One way to measure the eco-efficiency of materials is to consider the embodied energy. This energy relates to the energy required to extract the raw resources, transp ort the $m$ to a factory and process them into refined materials. One tonne of aluminium, for example, takes more than 100 times more energy to produce than one ton ne of sawn timber. In general, materials extracted from 
nature and requiring little p rocessing ten do be low e mbodied en ergy materials (typically 2$12 \mathrm{MJ} / \mathrm{kg}$ ), wh ile man-made materials tend to ha ve medium or $\mathrm{h}$ igh em bodies energies (typically $10 \mathrm{MJ} / \mathrm{kg}$ to over $1000 \mathrm{MJ} / \mathrm{kg}$ )" according to Fuad-Luke p. 23 [24].

At the op posite end of the re use/recyclability con tinuum are co mbined materials or product with a combination of materials in the $\mathrm{m}$ which probably rel $\mathrm{y}$ on specifi $\mathrm{c} d$ ifferences in physical o $\mathrm{r}$ ch emical $\mathrm{p}$ roperties to be re covered for reu se e.g. rec overy o f metals from consumer p roducts often relies on the use of $\mathrm{c}$ hemical so lvents or heat $\mathrm{w}$ hich affect $\mathrm{p}$ lastic content but not the metal content. The disadvantage of many of these 'solutions' is that much of the less desirable content is da maged or converte $d$ to o ther materials w hich ma $y$ be hazardous themselves and require subsequent processing even for just safe disposal.

A recently begun research project a $\mathrm{Brunel}$ University has the aim of developing a machine which is capable of directly reusing the items which it produces. Based on a well-proven and widely used rapid prototyping technology called fusion deposition in which the raw material in the form of a thermoplastic filament is deposited onto a platform (in much the same manner as a hot glue gun deposits glue from a nozzle) to build up, layer by layer, a complete item. Figure 6 shows a commercial variant of this type of machine.

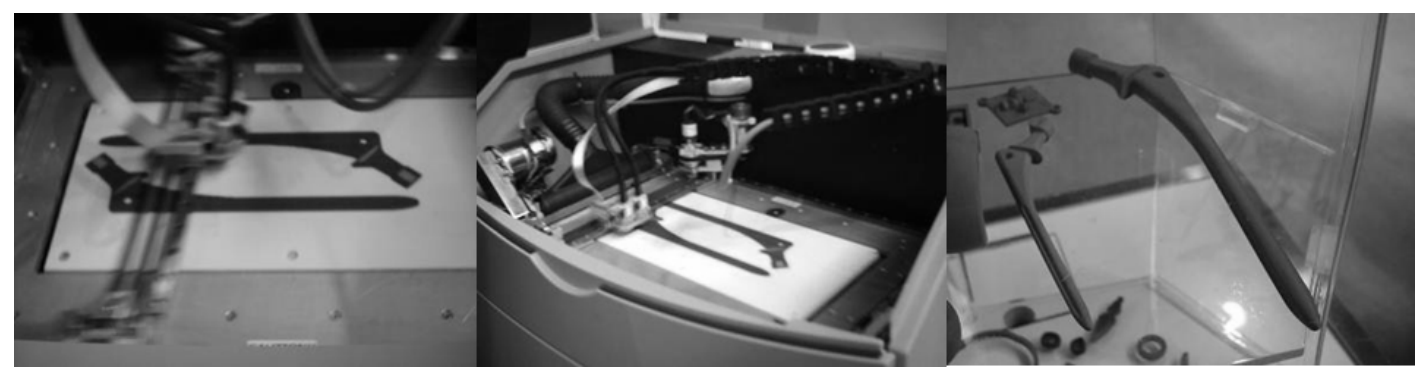

Figure 6: Unimatic FDM rapid prototyping machine

The first stage of the machine will be a shredder type device, capable of rendering the full or partial scrap plastic components previously $m$ ade $b y$ the $m$ achine $i$ nto small fragments or pellets. These fragments will then be fed into the se cond stage which w ill comprise a heated barrel with internal Archimedean screw (similar in design to that used in in jection moulding machines) which will melt and compact the plastic and drive it towards a nozzle, where it will be extruded to form a filament suitable for input to the deposition head of the FD M machine. The aim of the project is to develop a 'demonstrator' system where the three existing processes are $\mathrm{c}$ ombined into the o ne ma chine as illustrated by the $\mathrm{c}$ oncept d iagram for the machine shown in Figure 7. 


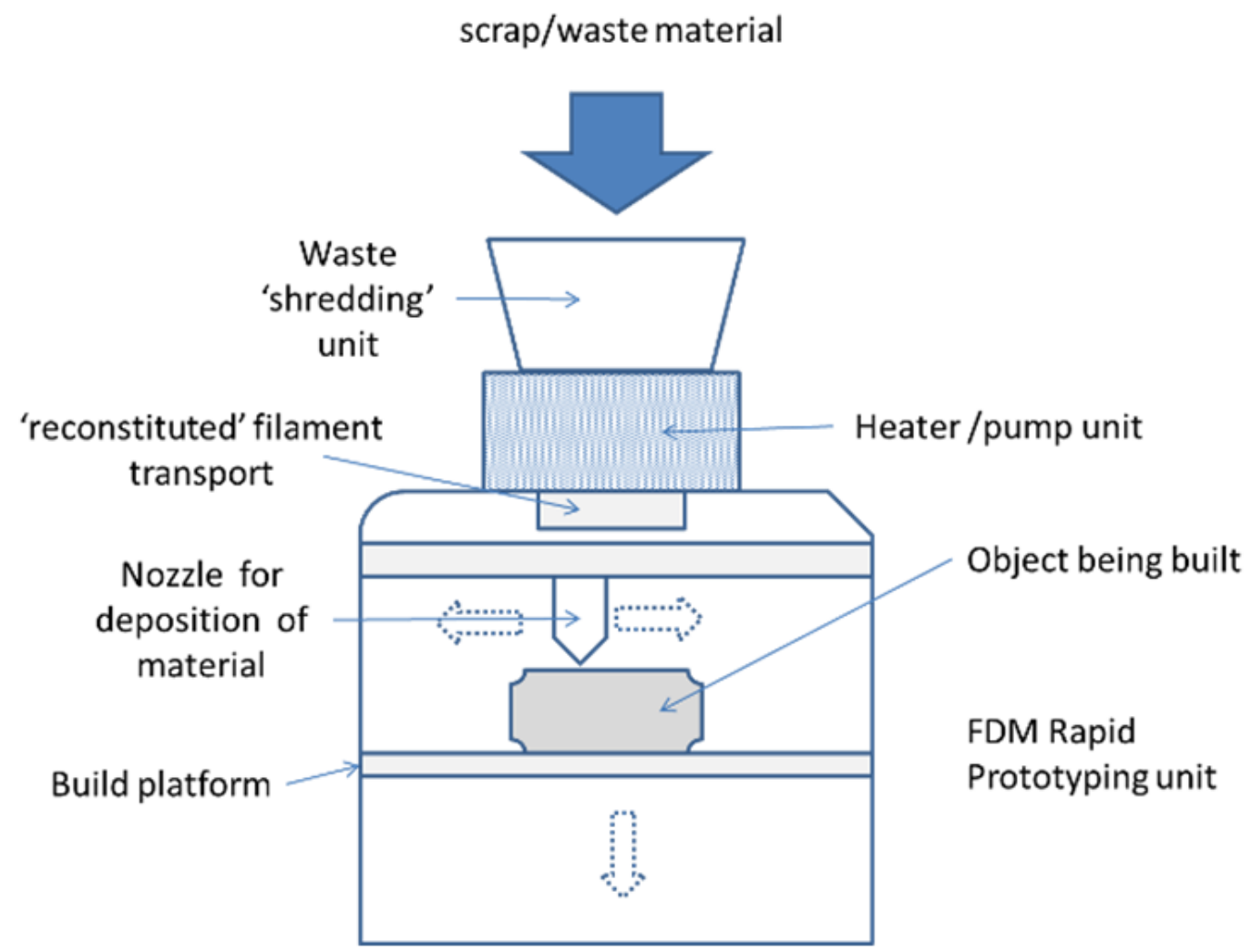

Figure 7: Concept diagram for the closed-loop manufacturing machine

In the case of this simple demonstrator machine, it is anticipated that the use of ex isting and well un derstood t echnologies should le ad to re latively few technical pro blems and issues surrounding contamination and suitability of the raw material (i.e. the items previously made by the machine) will initially be limited by good housekeeping practices. Issu es surrounding materials w ould of cou rse be orders of magnitude more p roblematic in a live co mmercial situation than in the laboratory, but material sorting and contamination issues are things which are already widely known in the rec ycling ind ustry. F or exam ple wit $\mathrm{p}$ lastic materials a number of trade bodies like the British P lastics F ederation (BPF) and natio nal/international standards like PAS103 and other directives, etc. are already in place.

It is clear that some manufacturing processes are more adaptable to direct reu se of material, those using single plastics or metals like injection moulding or casting being the most likely candidates, ho wever there will be, as one would expect, a nu mber of tech nical issues to overcome in order to develop even the simplest closed loop manufacturing. A secondary issue for direct clo sed loop manufacturing $w$ ill be to develop the manufacturing technologies and machinery with specific capabilities to allow for this idea. A quick trawl around the different commonly use $\mathrm{d}$ manufacturing $\mathrm{t}$ echnologies wo uld suggest that so me technologies will be more adaptable than others. Injection moulding and some versions of rapid prototyping are obvious candidates, whilst other technologies - in particular high precision machining - $m$ ay be too reliant on very specific and regular material properties to function with 'inferior' quality of materials. The concept of completely closed loop systems are p robably the manufacturing equivalent of 'perpetual motion' machines, so new materials will probably need to be added to 
improve the quality of the raw materials to acceptable standards and for some industries, e.g. medical device or aerospace, it may never be possible to use materials recycled at point of use.

However early we may be in the d evelopment cycle of $d$ irect closed loo $\mathrm{p} m$ anufacturing systems, the concept of using the scrap, waste and recyclable material as a direct raw material input to the same manufacturing process as was u sed to o riginally manufacture, despite the various issu es to overcome, is su rely worthy of pu rsuit. Further, energy a nd other environmental c onsiderations al so exten d beyond manufacture, espec ially for pr oducts that consume en ergy during their use. When an alu minium car leaves the production line it may have more embodied energy than an equivalent steel car, but the lighter aluminium car will be more energy-efficient when it is driven hence requiring lower levels of fuel consumption.

\section{Future research}

When bu siness models are based o $\mathrm{n} v$ irtual organisa tions $(\mathrm{V}-\mathrm{O}) \mathrm{t}$ he $\mathrm{V}-\mathrm{O}$ Leader $(\mathrm{t}$ he organisation with wh ich the consumers typically id entify with) $n$ eeds to develop a st rategic response to sustainability drivers (legislative etc..) which is reflected in their mission statement and pro duct strategy. Fu rther, the V-O Leader will h ave repo rting responsibility on the sustainability of the final product wh ich enta ils $p$ lacing susta inability metrics on the other firms in the lifecycle. Metrics will become the driver for management a ttention in the other firms who may have to look at new and alternative technologies in order to achieve energy and resource efficient approaches. Figure 8 highlights that management effort based around metrics is required to ensure integration

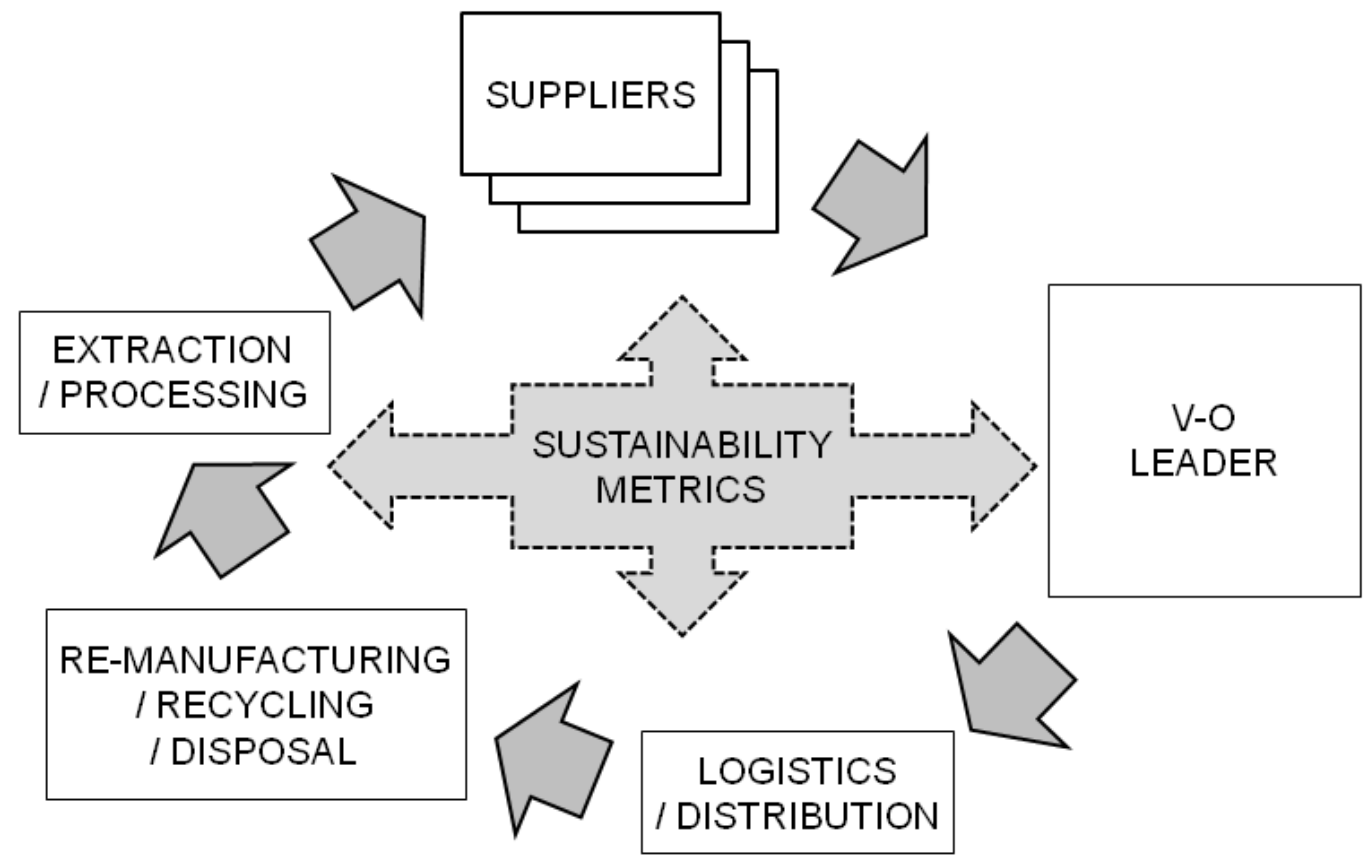

Figure 8. Closed loop production 


\section{Conclusions}

The paper started with a review of de sign approaches and product deve lopment in terms of 'open loop' versus 'closed loop' systems. In the context of consumer electronics products with its diverse a pplications, life cy cle a ssessment for su stainable product deve lopment has be en introduced as a susta inable dev elopment approach. The pro posed model for a susta inable product development process co mprises thre e stages fi rstly, a high l evel e xamination of product costing, secondly, life cycle design which concerns the more stra tegic p roduct and technology decisions and thirdly, life cycle analysis which involves a de tailed assessment of energy and other environmental impacts. By utilising a collaborative view of product design at the early stages, it provides a methodological approach to business and product planning across the supply chain. The implications of 'closed-loop' manufacturing are then examined including a conceptual proposal for a closed-loop manufacturing machine.

\section{Acknowledgments}

An e arlier versio $n$ of $t$ his material was $p$ resented in a conference $p$ aper at the 15 th A nnual Cambridge International Manufacturing $\mathrm{M}$ anagement Symposium on "Innovation in $\mathrm{g}$ lobal manufacturing - new models for su stainable va lue c apture", h eld Sep tember, 2010 at Cambridge University, UK and more rec ently at th e 2 1st Intern ational Co nference on Production Research, ICPR 21, held August, 2011 in Stuttgart, Germany.

\section{References}

[1] R. Hale, and P. Whitham, Towards the Virtual Organisation. McGraw-Hill, London, 1997.

[2] I. Bereketli, M.E. Genevois,. and H.Z. Ulukan, "Green product design for mobile phones", World Academy of Science, Engineering and Technology, vol. 58, pp. 213-217, 2009.

[3] L. M. E llram, W. Tate and C. R. Carter, “Applying 3DCE to environm entally responsible manufacturing practices" Journal of Cleaner Production, vol. 16, pp. 1620-1631, 2008.

[4] Miettinen, P., Hämäläinen, R.P., "How to benefit from decision analysis in environmental life cycle assessment (LCA)”. European Journal of operational research, vol. 102, pp. 279-294, 1997.

[5] J. Birkeland, Design for Sustainability: A Sourcebook of Integrated Eco-logical Solutions. London: Earthscan, 2007.

[6] J. Fiksel, Design for Environment: Creating Eco-Efficient Products and Processes. New York: McGraw-Hill, 1996.

[7] R.G. Cooper, "Product innovation and technology strategy". Research Technology Management, vol. 43, pp. $38-41,2000$.

[8] K. Prahalad and G. Hamel, "The core competence of the corporation”. Harvard Business Review, vol, 68, pp. 79-90, 1990.

[9] U. Tischner, and R. Nic kel, "Eco-design in the printing industry life cycle thinking: Implementation of e codesign con cepts and tools in to the rou tine proc edures of com panies." The Journal of Sustaina ble Pro duct Design, vol. 3, pp. 19-27, 2004.

[10] J. Fahy, "The resource-based view of the firm: some stumbling-blocks on the road to understanding sustainable competitive advantage". Journal of European Industrial Training, vol. 24, pp. 94-104, 2000. 
[11] K.M. Eisenhardt, and J.A. Martin, "Dynamic capabilities: what are they?" Strategic Management Journal, vol. 21, pp. 1105-1121, 2000.

[12] D.J. Teece, G. Pisano, and A. Shuen, "Dynamic capabilities and strategic management". Strategic Management Journal, vol. 18/7, pp. 509-533, 1997.

[13] D. Maxwell, W. Sheate, and R. van der Vorst, "Functional and systems aspects of the sustainable product and service development approach for industry". Journal of Cleaner Production, vol. 14, pp. 1466-1479, 2006.

[14] P. Mi ettinen, a nd R.P. Häm äläinen, "How to ben efit $\mathrm{f}$ rom deci sion an alysis in envi ronmental li fe cycle assessment (LCA)”, European Journal of operational research, vol. 102, pp. 279-294, 1997.

[15] W.P. Schmidt, and F. Butt, "Life cycle tools within Ford of Europe's product sustainability index. Case study Ford S-MAX \& Ford Galaxy.” The International Journal of L ife Cycle Assessment, vol. 11/5, pp. 315-322, 2006.

[16] S. Jo shi, "P roduct environmental life-cycle a ssessment using in put-output techniques." Journ al of Industrial Ecology, vol. 3, pp. 95-120, 1999.

[17] J. Jiao and M.M. Tseng, "A methodology of developing product family architecture for mass customization," Journal of Intelligent Manufacturing, vol. 10, pp. 3-20, 1999.

[18] C.H. Noble and M. Kumar, "Exploring the appeal of product design: A grounded, value-based model of key design elements and relationships". Journal of Product Innovation Management, vol. 27, pp. 640-657, 2010.

[19] H. Che sbrough and D. Teece, "Organising for innova tion: W hen i s virtu al v irtuous?" Harvard Business Review, vol. 80, pp. 127-136, 2002.

[20] M.J. Gallivan, "Striking a balance between tru st and control in a virtual organi sation: a content analy sis of open source software studies”, Information Systems Journal, vol. 11, pp. 277-304, 2001.

[21] R.W. Scholtz , and O. Tietje , “Embedded case study m ethods: integrating quantita tive and qualitative knowledge”, Thousand Oaks, Calif. USA. Sage Publications, 2002.

[22] J.J. Jacques, A.M . Agogino, and L. B.M. Guimara es, "Sustainable Pro duct dev elopment initia tives in the footwear industry based on the cradle to cradle concept", Proceedings of the ASME 2010 International Design Engineering Technical Conferences \& Computers and Information in Engineering Conference, IDET/CIE 2010, August 15-18, Montreal, Quebec, Canada.

[23] W. McDonough and M. Braungart, Cradle to Cradle: Remaking the Way We Make Things. NY, USA, North Point Press, 2002.

[24] A. Fua d-Luke, "Sustainable Design", The J ournal of the Institution of Engi neering Des igners, Ma rch/April 2008, pp. 22-25, 2008.

\section{Authors}

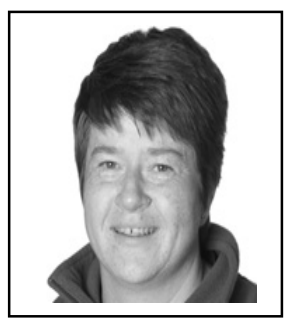

Dr. Rebecca De Coster is a lecturer of innovation in the School of Engineering and Design, Brunel University, UK. S he $\mathrm{h}$ as twelve years e xperience in the teleco ms se ctor i ncluding resea rch and consultancy based o $\mathrm{n} \mathrm{h}$ er pri or experie nce in telec ommunications planning. She received her BEng (Hons) in electronic and electrical engineering from Bir mingham University an $d$ he $r$ MBA $f$ rom the University of Ki ngston, London. S he earned her do ctoral degree from Brunel University examining in novation strategie s of $\mathrm{m}$ obile networking firms and th e a ssociated enterprise rea lignment $f$ or managing technology and innovation 


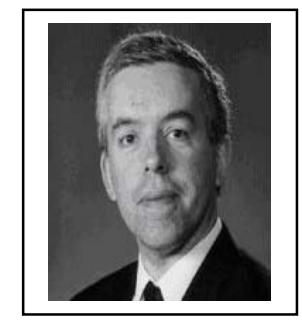

Dr. Richard Bateman is a Re search Lect urer in the Scho ol of Engineering and Design, Brunel University, UK. and is the co -ordinator of $t$ he Innovative $M$ anufacturing collaborative research network (IMCRN). He holds Masters d egrees in b oth Advanced Manufacturing Technology and $\mathrm{Bu}$ siness Administration a nd o btained $\mathrm{h}$ is $\mathrm{P} \mathrm{hD}$ in Manufacturing S ystems from Leed s Metropolitan Univ ersity. He has worked in $\mathrm{v}$ arious industrial ro les i ncluding manufacturing, business systems consultancy and as a commercial research scientist. His research interests includ e adv anced manufacturing technologies, rapid manufacturing and sustainable manufacturing.

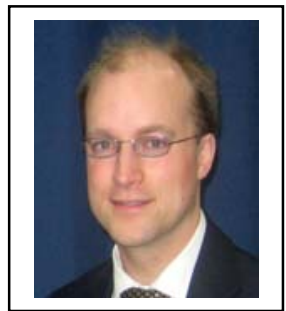

Dr. Alexander Plant studied Engineering and Product Design B.Sc. (Hons) at the University of Westminster, Design Studies M.A. at the University of Hertfordsh ire and has re cently co mpleted a Ph.D. i n Standards in Susta inable Engineering and Desi gn at Brunel University. Previous employment included interior design, military equipment in tegration, a nd industrial s torage s ystems design and testing. 